Spring 2016

\title{
UNDERSTANDING URBAN CHANGE IN ISTANBUL: FROM THE CAPITAL CITY TO THE CITY OF CAPITAL
}

\author{
(Revised in February 2017)
}

Baris Guven

\section{Introduction}

Istanbul served as the capital city of the Ottoman Empire for more than four centuries. In the $19^{\text {th }}$ century, the expansion of European capitalism led Istanbul, among other cities, to emerge as a port-city where the different routes of trade intersected and a small-scale industry was established. The foundation of Turkish Republic in 1923 was a turning point for the city as the new ruling elite aimed to eliminate the city's centuries-long political/economic domination and posed the new capital city, Ankara, as the new site for the centralization of power. Until the 1929 Great Depression, still had to operate its economy under the conditions of Lozan Peace Treaty, Turkish economy followed liberal polices. Experiencing the shock of the Great Depression and failed to see a significant economic progress in liberal years, Turkey chose, perhaps being the first periphery economy in the world economy, a very different direction to take in the 1930s: statist industrialization. The factories to produce the basic goods (particularly three whites; flour, sugar and textile) were established around the country. The transition to the multiparty system after the Second World War under the emergent US hegemony marked the shift in the regulation of the economy. In the 1950s, Turkey articulated to the world economy as an exporter of the wheat as the Korean War led to the rise in prices. The privatization of the state enterprises was aimed right after the WWII but never materialized under the pressing conditions as the cities started to expand. Even though Turkey did not enter WWII it was one of those countries that took the Marshall aid in the form tractors, signifying the new role in the world division of labor to which it was assigned. Therefore starting from 1950, cities but especially Istanbul became the hosts for the new migrants who willingly or unwillingly had to leave their original locations.

Right after the military coup in 1960, Turkey transformed itself into what is called developmental state. Until 1980, the year in which second military coup took place, the five-year development plans were implemented to lead and direct the industrialization. Even though the whole period brought significant benefits for the working class, a significant polarizing tendency in terms of the concentration of productive capacity and population worked itself out. Istanbul was sucking the population and industrial capacity. Within fifteen years, from 1965 to 1980, the city's population doubled, rising from 2.3 million to 4.75 million people. Another tendency was at work as well. The polarization of the population in terms of provision of housing was significant. The immigrants joining the working class had to build their own houses occupying the state-owned land, the result being a widespread phenomenon of gecekondus (built overnights). 
1980 marked the introduction of neoliberalism, among others, to the structure of Turkish society. Out of the triad of liberalization, stabilization, and privatization that defined neoliberalism, the first two took the lead. The militancy of the working class and the wage rates were adjusted downward. Never solving its foreign exchange problem in the import-substituting industrialization era under the lead of the developmental state and in fact ending the period with foreign debt, the new political rulers forced the economy to orient itself towards export. The need for foreign exchange (predominantly dollar) was decisive. The policies changed but the deep tendencies did not. Istanbul kept sucking the resources and population. In 2000 the population of the city reached 10 million. The inner polarizing tendency kept working as well.

Having ten percent of the population in its boundaries in 1980, Istanbul had to be restructured in the face of the crisis of ISI period. The global city discourse circulating in the city management circles was appropriated by the new management. In their own imagination, the city would not continue to get new industry investments. The deindustrialization of the city became a policy target for the city management. Attracting more and more tourists in the globalizing world was the new aim. However, the city kept growing as the new migrants continued to come. It continued to expand towards the north where the water basins and forests of the city are located. In addition to the construction of a central business district, the second bridge was constructed in the 1988 over the Bosporus.

The 1990s were the years in which coalition governments ruled the country and the economy was fragile, as it was in the 1980s, under the exegeses of the restructuring and finance capital. 2002 election was another turning point for the society. After all years of coalition governments, the Justice and Development Party, JDP (AKP), came to the power forming the one-party government. The stability was now the key word. Economic growth was less volatile under the one party government thanks to a set of factors: the banking sector was robust after the restructuring following 2001 financial crisis, the abundant credit in the world markets were flowing into the economy and the privatization was executed fast. An emerging tendency, the expansion of the construction sector, starting from the mid-1980s, gained momentum under the JDP. The increasing number of shopping malls, residential projects and office buildings continued to shape the urban landscape, Istanbul being the main location. The infrastructure projects played a key role in the discourse of the JDP. It was returning to the voters the development mainly in the form of bridges, highways, and airports all over the country. Any concern raised by interest groups over these projects was demonized by particularly then-prime minister now-president as foreign-related predicament to the development. Istanbul took a massive amount of construction investments as the private capital directed its attention mainly to this city as it did previously. Through the agency of an urban-rent coalition, the third bridge over the Bosporus and a third airport in further northern part of the city were initiated. On the Anatolian side of the city, the Istanbul Finance Center project was initiated aiming to concentrate the main financial institutions in Istanbul. The city population kept growing rising from 10 million in 2000 to 14.6 million in 2015, hosting the 18.6 percent of total population. 
How should we understand the post-1980 urban developments in the city? The literature over these issues focuses either this or that side of the general picture with unsatisfactory frameworks. This paper tries to offer a general framework to locate the urban developments in Istanbul. It is the claim of this paper that neither globalization and relatedly global city formation nor neoliberalism could be utilized fully to make sense of recent developments. The unchecked uneven development tendency in Turkish capitalism must be central to the analysis. The dynamics of overall economy and the institutional features of the sub-periods should also be incorporated into the analysis. In a nutshell, what the paper argues is that the problems related to the particular urbanization of Istanbul are the problems of the Turkish economy.

\section{Uneven Development of and in Istanbul: The Legacy of Import-Substituting Industrialization (ISI)}

By 1960s the urban landscape of the city was changing slowly. Squatter housing, Gecekondus, began to appear starting from mid-1940s both around the manufacturing plants in the center of the city (around the Golden Horn (Halic) waterway) and in the new urban fringes where mostly small-scale enterprises were set up cheaply. Gecekondus became the main way of new housing in the 1950s in which the mechanization and commercialization of agriculture in the rural areas accelerated the exodus of the rural population following the introduction of tractors with the Marshall Aid (Enlil 2011, 9).

1960 marked the beginning of the ISI in Turkey. Under the indicative planning practices of the State Planning Organization (SPO) with the direct but limited involvement of the state in production, both Turkish economy and the economy of Istanbul burgeoned. The growth was buoyant, and capital and people flowed to the city in massive ratios:

Sixty-five percent of new enterprises established in Turkey in ... [ISI] period were located in Istanbul. The bulk of foreign investment was targeted on Istanbul (although the total was modest). Under the First and Second Five-Year National Development Plans, Istanbul received the lion's share of public expenditure. Against this supportive background, the number of both small and large-scale industrial enterprises in Istanbul doubled between 1950 and 1964, increasing from 15,000 to 30,000 establishments. It then grew by a further $82 \%$ from 1964 to 1972 with an increase in added value of $305 \%$. In the 1950 s only $20 \%$ of Turkey's small and larges-scale industry had been located in Istanbul; by 1980 this had risen to $46 \%(10)$.

The increase in the city's population was equally remarkable. It rose from almost 2.3 million in 1965 to more than 4.7 million in 1980. Most of this growth was due to new immigration and the higher birthrate of immigrants (Keyder 1999a, 146). To the uneven development of the city compared to the other cities, the uneven development in the city that already began in mid-1940s was added with its urban planning dimensions. The disorder in the city was striking the overall planning rhetoric nonetheless: 
the jigsaw pattern of established private property, abandoned non-Muslim holdings, waqf land without claimants, former agricultural land, and above all various kinds of publicly owned land, translated into a similarly unpredictable intertwining of zoned and gecekondu settlements, resulting in a surprising juxtaposition of villas and expensive blocs of flats with shacks, even in the wealthiest neighborhoods of the city (ibid.).

Figure 1: Istanbul's population and its share in total population from 1965 to 2015

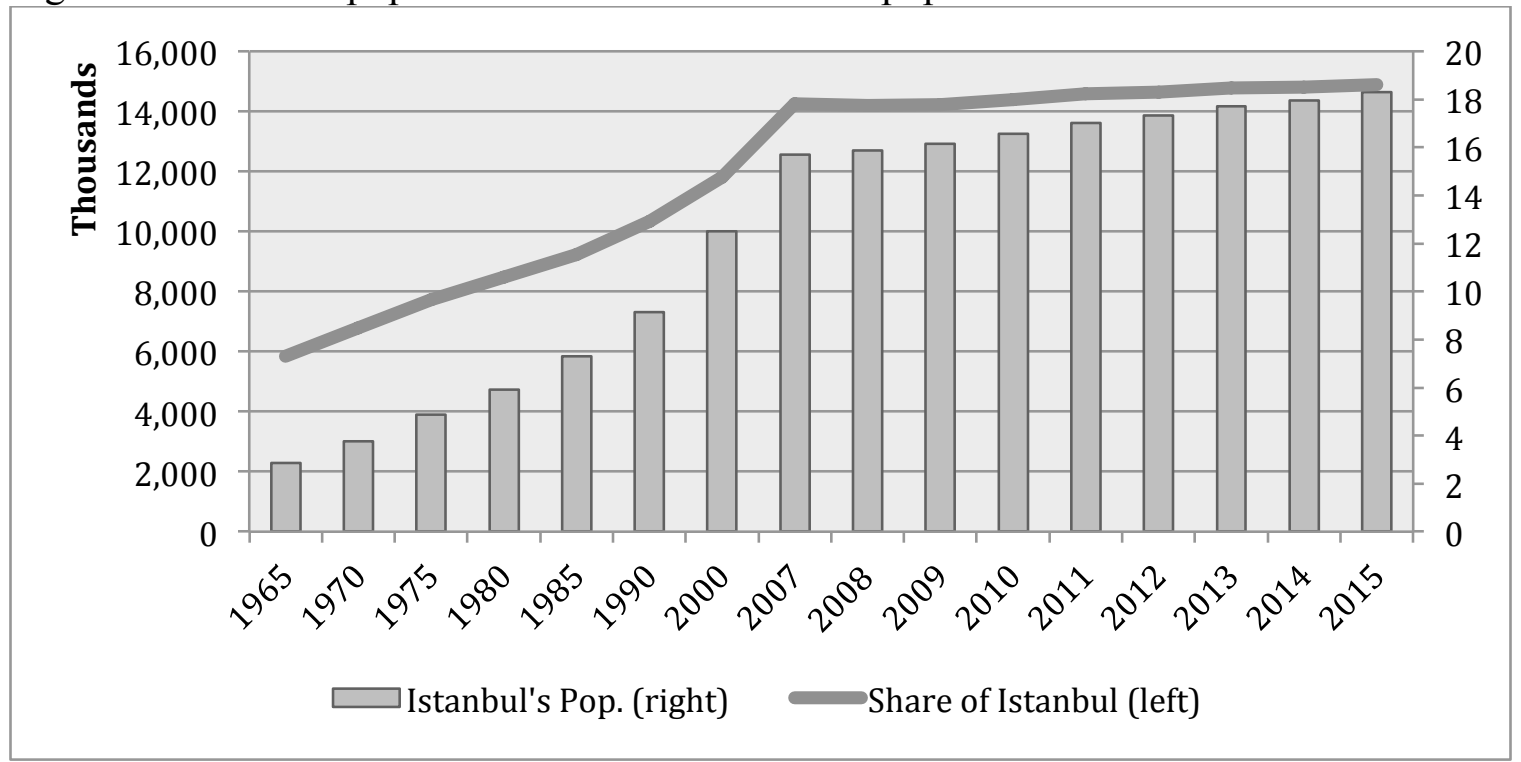

Source: Turkstat

The point here is not only the lack of urban planning in the booming city. However, it could be argued that the solution of the problem when it first appeared would create a balanced geographical arrangement of the settlements limiting the legitimizing role in the neoliberal era of the existing disorder. What needs to be stressed is the fact that new immigrants were not provided public housing service. The overall period brought with it significant gains for the unionized workforce (Boratav 2008). Nonetheless neither state nor private capital was interested in the provision of (decent) housing to the large segment of the working-class. As the private capital focused on the middle and upper segments of the society the pressing need for housing forced the immigrants to construct gecekondus. The acquisition of the land by the new immigrant was 'illegal'. Even though the authorities occasionally demolished gecekondu settlements, the mere number of the inhabitants forced the local government and politicians to grant them the property rights through amnesties and pardons in exchange for their votes. After the ownership is obtained, they converted their houses into apartment buildings by adding new flats and these were either sold or rented out. "The Gecekondu areas thus gradually became 'commercialized' over time and a market dominated by 'squatter lords' began to emerge" (Enlil 2011, 12). Therefore, in addition to pure economic integration of the immigrants to the city, this also meant physical integration. As Keyder rightly puts it:

\footnotetext{
${ }^{1}$ For a similar observation in various countries, see (Davis 2006).
} 
Incorporation of the new immigrants into the modernizing social order could not have occurred without their physical integration operating through the acquisition of housing: the dynamics of incorporation depended closely on the ease with which immigrants closely could access land and housing. ... The acquisition of a house meant the definition of residence and locality. It provided the potential for the mobilization of networks which were substantially locality-based and permitted the utilization of patronage mechanisms, for material and ideal rewards alike, through a politics conducted at the local level (Keyder 2005, 125).

The growing need for housing, the scarcity of the land in the planned locations of the city, and the skyrocketing land values gave rise to another form housing provision, known as 'build and sell' (Enlil 2011, 13). In this peculiar form, the land by the landowner who had not enough capital to undertake costly production of buildings and the capital by the entrepreneurs who did not have enough capital to buy land were put together to extract the rising land values. Therefore, under the two inter-related uneven development tendencies, the city and its resources were put under an unprecedented pressure. The irrevocable expansion of the city urged "all sectors of society to build and gain something out of rising land values" (ibid.), i.e., urban rent.

\section{Urban Change in post-ISI period and Neoliberalism}

The introduction of neoliberalism into Turkish society required a military coup in 1980 . The working class was suppressed, the organized social opposition was tamed and the wage rates were reduced to restructure the economy from the previous importsubstituting configuration in which inward-oriented costly capital accumulation permitted relatively high wages rates to an export-oriented economy in which wage rates had to be reduced to increase competition given the technological backwardness of Turkish capital. This required trade liberalization and the introduction of a set of export promotion incentives.

The efforts to reorient the economy need to be viewed in the light of the relative position of the economy vis-à-vis the world economy. The peculiar social structure of the Turkish economy did never reach the stage of producing the capital goods during the ISI period. A comparison is in order here. Both South Korea and Turkey entered 1960s with a military coup. Substituting import with domestic production was the long-run target for both economies. Their paths of development began to diverge from the beginning. Particularly, in South Korea, the allocation of foreign exchange by the state to private capital depended on the latter's success in achieving export targets (Amsden 1989). In Turkey, in contrast, domestic production increasingly relied on the provision of foreign exchange by the state to private capital with no respect to the private capital's foreign exchange earning record. The inability of the economy to earn foreign exchange in order to buy technology (capital goods) and the de facto liberalization of the imports (consumer goods), combined with the 1973 oil shocks, pushed the economy into debt (Pamuk 1987). As it is shown in Figure 2, starting from the mid-1970s, the debt stock of the economy as a share of the exports and primary income (represented by solid line) skyrocketed by 1980 (measured on the left axis). Correspondingly, the ratio of total reserves to external 
debt plummeted and the share of external debt in the gross national income started to increase (both measured on the right axis). Therefore, the export-orientation under the supervision of IMF and World Bank appeared as a necessity for the national government and capital to overcome the foreign exchange bottleneck.

Figure 2: Turkish Economy in Debt, 1970 - 2014

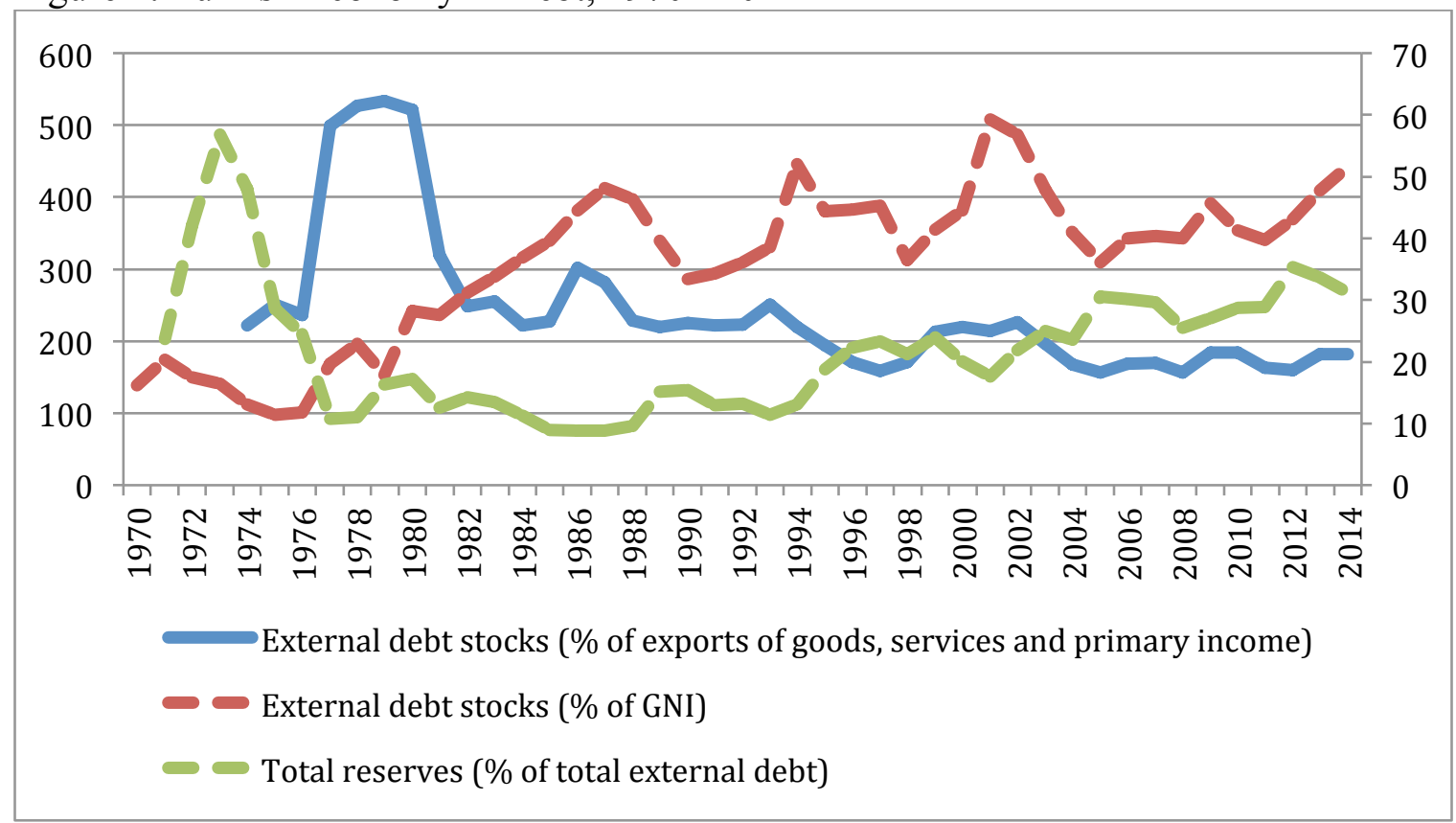

Source: IMF

\subsection{Selling Istanbul}

We now turn to Istanbul's more than thirty-year experience by highlighting the main developments in the city's urban restructuring. Two sub-periods are identifiable: the period from 1980 to early 2000s and the post-2002 with JDP being one-party ruling government to the present time.

It was Istanbul the restructuring of which paralleled the restructuring of overall economy. One of the leading social scientist in Turkey, Caglar Keyder, in his most-cited work on the transformation of the city, argued that the historical position of the city as a node where the different trade routes intersected and the manufacturing industry located, and its geographical position in the broader region including the Middle East, Europe, and Caucasus privileged it as a new location for the producer services at a supranational level in the globalized world. In his discussion informed by the global city literature, he also argued that this golden opportunity nonetheless, the country failed to create the suitable environment for the global capital (Keyder 1999b, 18). In fact, he went on to say that, the city experienced a limited transformation as suggested by the global city literature:

There is a flourishing service sector in marketing, accounting and management, telecommunications, banking and finance, transport, insurance, computers and 
data processing, legal services, auditing, accounting, consulting, advertising, design, and engineering. World transnationals have penetrated this sector through joint ventures, direct investment, and licensing. ... In the all important FIRE services (finance, insurance, real estate) employment has grown by one hundred thousands jobs, between 1980 and 1990, from 10.3 percent to 13.9 percent of the service sector, or 5.3 percent to 7.1 percent in Istanbul's total employment. ... These are all located in the newly developing business districts with their tall office buildings encased in glass in the international mode. All this development, however, is slowed down by uncertainty, ambivalence, and lack of legislative and physical infrastructure (19; emphasis added).

What was not provided to the global capital, according to Keyder, was the global system of information flows due to the inability of the state in privatization of the transportation and telecommunications. Similarly, the airport capacity had not been expanded to accommodate the growing number of passengers. Therefore, the global city project took half way, and the really existing globalization shaped the city: Istanbul emerged as major center for money laundering and drug trade, and the exceeding unevenness "in terms of access of the denizens to globalized activities and in terms of the physical spaces under transformation" with the "disparities in income, consumption patterns, and lifestyles" marked its stamp over the city (19-23). ${ }^{2}$

We instead argue that global city framework has a very small explanatory capacity, perhaps none, to make sense of the post-1980 urban change in Istanbul. For one thing, even if we accept the mechanic re-division of labor in the cities, the problem that Istanbul faces is not particularly this or that kind of capital lands in it, but the mere continuation of the concentration of resources and the resultant pressure over the Istanbulites and environment and hence the future of the city. The expansion of the city to the north continued as a new central business district preferred to locate itself away from the historic city center. Moreover, the very same argument over the capacity of the city to accommodate ever-increasing human and capital flow is recently appropriated by the JDP government to create consent for the construction of the third airport, and third bridge over the Bosporus, all to the north of the city center.

Second, as Öktem (2011) argues, the global city literature do not pay any attention to the local forces and their economic and political aspirations. The crux of the global city argument is that economic globalization brought the shifting of manufacturing from costly developed to cheap developing countries and the corresponding emergence of the global cities as places where producer services and financial activities are located, and

\footnotetext{
${ }^{2}$ Keyder even suggested that the aforementioned inability of the state either in providing those services in good quality or privatizing them led to shunning by global capital. After all, in Chile, Argentina and Mexico, foreign capital accounted for between 10 and 20 percent of capital formation whereas in Turkey only 2 percent. However, he does not cite any work showing the supposed relationship between the privatization of those services or qualified provision of them by the state and the flowing in of foreign capital. As a first approximation, however, it could be said they were equally unstable as Turkey in the 1980 s as the debt crisis hit them.
} 
operated in the global scale, over-simplifying the "factors underlying the restructuring of the world economy and the role of cities" and "urban policy decision-making" (29).

The global city hypothesis has thus led too many researchers to focus narrowly on those identifiable economic flows that are supposedly driving urban change, such as international financial transactions, the increasing importance of the service sector and flows of information, technology, capital, image, and so forth. The global city discourse has highlighted processes rather than actors, and has thereby obscured power relationships and the fundamentally political character of urban development and policy formation (29).

Among the cases Öktem presented one is particularly important. It is argued that the deindustrialization of New York was the aim of its most powerful players, particularly the real estate, insurance and financial industries to utilize the real estate holdings for more profitable purposes such as for large office buildings and luxury housing (30). This is also interesting as the investment banks from the same coalition did impose on the city the first austerity of the neoliberalism in mid-1970 (Tabb 1982).

Third, we even need to go beyond this position to take into account the impact of the crisis of national/global capital on the restructuring of the city. One of the tendencies that have been observed in the cities is their search for being a consumption location in order to earn revenue (tourism etc.). For instance, Harvey (1989) argues that the crisis of Fordism and the need of the city economies for revenue forced the cities to rearrange themselves to attract people for consumption. Similarly, one needs to take into consideration the influence of the crisis of ISI over the urban decision-making in Istanbul.

After 3-year suspension of civil politics under the military rule, the Motherland Party came to power with the 1983 election. The mayor of Istanbul from this party, Bedrettin Dalan, using the new executive powers granted by the transfer of authority for coordination and administrative action from the central government (two-tiered metropolitan government model) initiated an 'entrepreneurial restructuring' project to transform the city. It included the cleansing of the industry established in the ISI period from the shores of the Golden Horn to clean its waters under the project sponsored by the World Bank, the expansion of the Tarlabasi Boulevard by clearing away nineteenth century inner-city housing, building wide avenues along the shores of the Marmara and the coastal road on the European side of the Bosporus (Enlil 2011, 17). As Keyder depicts:

Istanbul was rapidly becoming a city designed for cultural consumption, easier to visit, with a well-defined tourist area containing monuments and heritage quotations in the form of restored neighborhoods, readily accessible from the newly built hotels (Keyder 1999b, 17).

In the new imagination by the city management, Istanbul was a product to sell to earn foreign exchange. As we argued above the ISI period ended up with the foreign debts and current account deficit as well, and the imposition of the export-oriented industrialization 
on the national scale appeared as a necessity. The stability of the economy desperately needed foreign exchange. It was in this context that selling Istanbul as an internationally attractive destination emerged. ${ }^{3}$ The new management did not aspire for only tourists but also for business conference traffic and international organizations. The Act on the Promotion of Tourism was enacted in 1982 to permit the central government to declare certain strategic sites as 'Tourism Centers'.

The Act vested all planning powers for 'Tourism Areas' with the central government, which could then bypass local planning regulations and grant increased building rights. It did not take long before the provisions of this law were also used to grant 'special' building rights to uses other than tourism, especially new expansions of the CBD [Buyukdere-Maslak]. Between 1984 and 1993 some 40 areas were declared as tourism centers, or 'tourism and business centers', which allowed the building of the high rise office towers and deluxe hotels in Istanbul (Enlil 2011, 15).

We are unable to have tourism revenues series for Istanbul going back to 1970s. However, available data for Turkey in general could be used to guess-estimate the effect of the policy and highlight the importance of tourism revenues for the financing of the current account deficit. After plummeted in the 1970s, the ratio of the tourism revenues to the imports recovered starting from the early 1980s (reaching around negligible three percent on average). In contrast, the ratio of tourism revenues to the exports rose from five percent in early 1980 s to over 25 percent in late 1990 s, being an important foreign exchange source for the import-dependent economy (IDA, 23). Nonetheless, what is equally important here, as the quote suggests, is the fact that the existing planning codes had been dismissed to capitalize on the rising urban rent within an environment the contours of which were drawn by the national economy's problems. ${ }^{4}$

Another big intervention to the city where the global city discourse was instrumentalized was the building of a new international business district in the Buyukdere-Maslak area (starting from Sisli and passing through Zincirlikuyu and Levent). This area was countryside until the 1950s. During the ISI period, both stateowned enterprises and pharmacy, textile and automobile parts manufacturers (the later between Zincirlikuyu and Levent on the left side of the axis) preferred to locate in this area with accompanying growth of the squatter settlement. Anticipating the rise of the land value in the future, some of the largest holding companies (such as Sabanci Holdings, Yapi Kredi Bank and Is Bank) bought land between Zincirlikuyu and Levent on the right side of the axis, opposite the large manufacturing establishments. Even

\footnotetext{
${ }^{3}$ See Harvey (2007) on the emergence of the first selling the city campaign in New York City by the city management under the directives of financial and corporate capital following the fiscal crisis of the city in the mid-1970s. It should be noted that it is not globalization but the planned intervention of the city elites that shaped the city's advertisement campaign.

${ }^{4}$ Neither Enlil nor Keyder situates the aspirations of the city and country elite to sell the city in the crisis of ISI. It is suggested that it took place as a natural result of globalization. This is particularly interesting as far as Keyder is considered as he studied the ISI and its crisis. In any case, the notion globalization becomes everything and, in fact, nothing.
} 
though the holdings demanded the right to construct their administration centers in the axis, the Istanbul Master Plan Bureau opposed this by arguing that the further expansion of the axis on the edge of sensitive forest era and water basins to the north would create environmental damage and suggested the Marmara Sea coast for sustainable development. After 1984, the demands by the five large capital groups reappeared on the surface and no matter the suggestion of other locations for the new CBD, the BuyukdereMaslak axis became the new international business district (Öktem 2011, 31-2).

The global city discourse mobilized by the MP [Motherland Party] insisted that Istanbul had no choice but to acquire the built environment and infrastructure appropriate to an international business class. The future of Istanbul was imagined as a modern, contemporary city with skyscrapers, wide motorways, luxurious hotels, new shopping centers and up-market residential areas (ibid., 33).

The pressure from the most powerful holdings of Turkey translated into the permission of high-rise building permissions nullifying the recommendation of the Master Plan Bureau. A series of business centers, hotels, shopping malls, and administration centers for national and international enterprises have been established from that date to the present time with a brief opposition period to the trend during the Social Democratic municipality administration, the result being a dramatic change in the urban landscape. What needs to be emphasized is, as Oktem suggests, the instrumentalization of the global city discourse in the realization of the construction projects, and the relentless search of private capital for appropriation of rising urban rent.

One peculiar public institution in the case of Istanbul that would play an important role in the transformation of the city was the Mass Housing Institution (TOKI). It was founded in 1984 to address the housing problems of low-income people by encouraging the establishment of housing cooperatives with the cheap credit support (Türkün 2011, 65). It also took the responsibility of the construction of the standard housing units in mass numbers. Between 1984 and 1999 TOKI constructed more than 100,000 units in mass housing areas, taking the form of high-rise and almost identical apartment blocks. (Enlil 2011, 18). In addition, as a result of the enactment of several laws from the mid1980s onwards, many squatter housing owners were given pre-title deeds that could be converted into official title-deeds with the preparation of development plans. Urban rent continued to serve as the main motivator for everybody owning property to invest in:

This policy was intended to transform these 'informal' housing areas by opening them to market forces. It strengthened the rent-earning potential of squatter-built housing, and for many of the new-recognized owners this began to be an important factor motivating further construction. Gecekondu owners started to convert their houses into low-quality apartment blocks, sometimes for the use of their children but sometimes for rental to provide extra income. As this commercial influence became more important, it began to restructure the squatter areas, leaving new divisions that now constitute very difficult problems in many squatter housing districts (Türkün 2011, 65). 
In the $1990 \mathrm{~s}$, the attitude of the city management, but especially TOKİ, towards squatter settlements shifted under the pressure of rising urban rent. Some settlements were located either in the inner city or the central areas of the expanding city. The squatter area dwellers were now 'invaders'. "Gecekondu districts were said to be the main cause of rising urban crime and political extremism, later identified with Kurdish immigrants from the southeast" (ibid.). The direct intervention to displace the hitherto dwellers for the initiation of urban regeneration projects, however, waited for the JDP government. Particularly, in 2004, TOKI was transferred from the Ministry of Public Works and Settlement to the Office of Prime Minister, and it was only to then-prime minister, Erdogan, TOKI was accountable. A very effective urban rent coalition was to be constituted with the close ties between the government and construction-oriented capitalists pushing the limits of the city with not just residential or office building projects but also with mega-projects. The ascription of the stability of the economy to the rule of one-party government, after the years of unstable coalition governments in the 1990s, translated into the opening of the way of doing construction business easily. A number of owners of soaring construction companies materially supported the JDP and it paid back its debt by utilizing its legislative power to enact the required laws and using the violence monopoly of the state to suppress the opposition.

Before proceeding further, we need to emphasize that even though the overall Turkish economy and society was subjected to the neoliberal configuration, the severity of neoliberalism in the period between 1980 and 2000, as far as the urban change in Istanbul is considered, remained relatively low. The unleashing of the neoliberalism in Istanbul waited for the JDP. Instead, we argue that the uneven development in Turkish economy privileging Istanbul as the main location for capital has to be prioritized to explain the rising urban rent and the continuation of the flow of capital to the city. Similarly, its historic legacy and geographical position was later appropriated to find solutions to the crisis of the economy. Though the mobility of international capital after the 1970s played a role in the transformation of the city its impact remained weak. Therefore, both globalization and global city as notions suggested in the literature do lack of intended explanatory power. We also argue that the neoliberalism superimposed itself onto the deeper tendencies of Turkish political economy. We now turn to this aspect.

\subsection{Urban Rent Coalition in the post-2002 Period: Neoliberalism Unleashed}

Due to lack of space, we will not provide an inventory of the urban ravages of neoliberalism. However, some major events will inform the discussion in this section. Under the rhetoric of global city, with the push of shocking 1999 earthquake, what unfolded in Istanbul was the consolidation of urban rent coalition. Rising land values and the high sale prices and rentals due to the soaring demand of the Turkish (and MiddleEast upper classes) population, who culturally conceived the real estate most secure investment, stimulated the unquenchable appetite of capital for valorization. 
The first urban regeneration project took place in Ayazma Gecekondu village on the edge of a small valley in the Kucukcekmece district on the European side of Istanbul. ${ }^{5}$ TOKI proposed to built a set of new mass housing projects for upper-class and up-market private estates. In 2004, Ayazma and Tepeüstü neighborhoods were designated as regeneration areas. Ayazma village was inhabited by relatively young and poor people and nearly all of them were Kurdish. The closeness to a factory district and the settling of earlier migrants from the South East were the two main reasons for people to settle here. A common strategy that would be applied in other urban regeneration projects was initially put into work here:

TOKI approached the residents of Ayazma with an offer. As in other Gecekondu renewal projects, the municipality was first to determine who were the 'rightful owners' of the buildings (tenants were also initially regarded by the Municipality as 'rightful', but this was forgotten later in the project). 'Rightful owners' were offered the chance to buy a new TOKİ-built flat in Halkali-Bezirganbahce (visible from Ayazma a few kilometers to south), for 200-250 TL per month, increasing in six-monthly periods, for 15 years. Those who had title deeds could return to Ayazma if they paid the difference between the value of the new houses to be built there and the Gecekondu they had vacated. But the financial details were mysterious, as was the timetable for completion of the new housing, which few thought they would be able to afford. In the event all but a handful agreed too move to the new estate. Although a formal agreement was signed between TOKI and the inhabitants of Ayazma, the result was in effect an eviction (Lovering and Türkmen 2011, 83).

The local opposition to the eviction by the residents of Ayazma nonetheless, the displacement took place. Those who moved to the new TOKI tower blocks in HalkaliBezirganbahce soon realized that they could not afford the rent. About one-third of them left. Moreover, the living conditions in the new blocks were worse than in Ayazma (ibid., 86). It should be added that the eviction was nothing more than accumulation by dispossession as the hitherto residents were either forced to pay rent for new houses or lose eventually what they initially had.

Among several laws enacted in 2005, the Law No. 5366 on Conservation of Deteriorating Historic and Cultural Property through Renewal and Re-use particularly targeted slums in the historic city center (Türkün 2011; Karaman 2008). The law gave the municipalities responsibilities "for 'the conservation and repair of cultural and natural heritage', for 'defining the scope of urban regeneration and development projects, for the provision of development of land and housing, for the conservation of urban history and cultural heritage', and for the utilization of 'special planning tools' in these areas" (Türkün 2011, 66). It was this law after which a set of major regeneration projects were initiated, demolishing the slum settlements in the well-known historic sites of Istanbul: Sulukule, Tarlabasi, Suleymaniye and Fener-Balat (ibid.). Out of these, Sulukule has been home to "one of the oldest sedentary Roma communities in history, dating back to

\footnotetext{
${ }^{5}$ The Olympiad stadium opened in 2002 near the Ayazma village.
} 
the Byzantine Empire" (Karaman 2008, 522). The same strategy that was applied in Ayazma case, offering the hitherto residents the flats in the new blocks on condition that they pay the difference between the value of the new flat and the value of the house they vacated, was applied here. Even though they were offered housing in mass housing project a different location, they had to pay installment. However, the Romans were very poor people making their living as vendors on the streets. The regeneration project turned into a de facto eviction and dispossession of local people. ${ }^{6}$

The culmination of the urban rent coalition's efforts to appropriate the urban land was the initiation of three mega projects, all in Istanbul. Istanbul Finance Center was initiated in 2009 (on the Anatolian side of Istanbul). It is a project with regional and global aspirations to create and build a financial district in Istanbul that would host the Central Bank of the Republic of Turkey, Banking Regulation and Supervision Agency, the state banks, and possibly later private banks and other financial institutions. The third bridge over the Bosporus and the associated North Marmara Highway initiated in 2013 is a big infrastructure project. As it was aimed in the construction of previous two bridges over the Bosporus (first opened in 1973 and second in 1988), it is aimed to reduce the excess commuting time spent in traffic, eliminate the related production and productivity loss, save fuel, to cheapen shipping, to enhance trade capacity and transportation alternatives, etc. ${ }^{7}$ The third airport is another mega project for Istanbul with global aspirations. Initiated in 2014, the airport would be the largest airport in the world with the highest passenger capacity. ${ }^{8}$ It is also projected to build a new settlement area. The cost and benefits of these projects have been debated from the point they announced. What is indisputable is the rising land values near the project areas and the continuation of the land development in the future. There is a vicious circle here: the high rent potential of the city attracts capital and the new investments push up the urban rent allowing the concentration capital and people in the city.

\section{Conclusion}

In this paper we argued that the urban change in Istanbul in both the pre- and post-1980 period should be understood as a combination of several factors. The uneven geographical development of Istanbul compared to other cities was the foremost tendency that defined the history of the city in the Republican period. In spite of the supposed planning practices in the ISI period the concentration of the capital and population in the city continued unchecked. In addition, the immigrants were not provided decent housing

\footnotetext{
${ }^{6}$ The wealthy people from some Middle-East countries purchased flats in mass numbers. It is a common priority among construction companies in Turkey to pay attention to the provision of what is demanded by foreign consumers. The existing income inequality in Turkey willy-nilly forces the companies to turn to the wealthy segments of neighbor countries' population. In any case, selling Istanbul by selling housing to appropriate the urban rent is, for its part, what shapes the urban landscape.

${ }^{7} \mathrm{http}: / / \mathrm{www} .3 \mathrm{kopru} . c o m /$ proje/projeninkazandiracaklari (the official website created for the bridge).

${ }^{8}$ http://www.igairport.com/iga-hakkinda/hakkimizda (the official website created for the airport). The businessmen who won the tender are known as the close allies of Erdogan. Both projects (the bridge and the airport) are being constructed in the north of the city where the sensitive forests and water basins are also located. As we stated above, the development of the city to north had been considered environmentally risky until the 1980s.
} 
and this led to the spontaneous formation of squatter settlements near the manufacturing industries. By 1980s the city's population and the production capacity soared. The urban rent did play a role but it remained weak in shaping the urban landscape. The main factor was the concentration of capital and population. The crisis of ISI in the late 1970s paved the way of the built-environment investment to attract foreign consumers to the city. By 1990s, the city's uneven development accounted for the continuous change in the urban landscape. The gated communities, central business districts, shopping malls, and hotels with the never disappearing squatter settlements defined the city: the city was more fragmented than ever. The outright neoliberalism was incorporated into the transformation of the city with the JDP government. Several urban regeneration projects brought the gentrification of Gecekondu areas and the supported the accumulation of private capital by dispossessions. The deeper tendency kept playing its role. What was new under the JDP's rule was the clear-cut consolidation of the urban rent coalition with a wide range of urban projects of various sizes continuing to put too much pressure on the shoulders of the historic city.

\section{References}

Amsden, Alice H. 1989. Asia's next Giant: South Korea and Late Industrialization. New York: Oxford University Press.

Boratav, Korkut. 2008. Türkiye Iktisat Tarihi, 1908-2007 (The Economic History of Turkey, 1908-2007). 12th ed. İmge Kitabevi Yayınları. Ankara: İmge Kitabevi.

Enlil, Zeynep Merey. 2011. "The Neoliberal Agenda and the Changing Urban Form of Istanbul." International Planning Studies 16 (1): 5.

Harvey, David. 1989. The Urban Experience. Baltimore: Johns Hopkins University Press.

- 2007. "Neoliberalism and the City." Studies in Social Justice 1 (1): 2-13.

IDA. n.a. "Tourism in Istanbul and Turkey (in Turkish)." Istanbul Development Agency. http://www.istka.org.tr/content/pdf/10---Turkiye-ve-istanbul-Bolgesi'ndeTurizm.pdf.

Karaman, Ozan. 2008. "Urban Pulse-(RE)Making Space for Globalization in Istanbul." Urban Geography 29 (6): 518-25.

Keyder, Caglar. 1999a. "The Housing Market from Informal to Global." In Istanbul: Between the Global and the Local, edited by Caglar Keyder, 143-59. Lanham, MD: Rowman \& Littlefield.

—. 1999b. "The Setting." In Istanbul: Between the Global and the Local, edited by Caglar Keyder, 3-27. Lanham, MD: Rowman \& Littlefield.

- 2005. "Globalization and Social Exclusion in Istanbul." International Journal of Urban and Regional Research 29 (1): 124-34.

Lovering, John, and Hade Türkmen. 2011. "Bulldozer Neo-Liberalism in Istanbul: The State-Led Construction of Property Markets, and the Displacement of the Urban Poor.” International Planning Studies 16 (1): 73-96.

Öktem, Binnur. 2011. "The Role of Global City Discourses in the Development and Transformation of the Buyukdere-Maslak Axis into the International Business District of Istanbul.” International Planning Studies 16 (1): 27-42. 
Spring 2016

Pamuk, Şevket. 1987. "Ithal Ikamesi, Doviz Darbogazlari ve Türkiye, 1947-1979 (Import Substitution, Foreign Exchange Shortages and Turkey, 1947-1979)." In Kriz, Gelir Dağılımı ve Türkiye'nin Alternatif Sorunu (Crisis, Income Distribution, and the Problem of Alternative in Turkey), 2nd ed. Kaynak Yayınları 24. İstanbul: Kaynak Yayinlari.

Tabb, William K. 1982. The Long Default: New York City and the Urban Fiscal Crisis. First Printing edition. New York: Monthly Review Press.

Türkün, Asuman. 2011. "Urban Regeneration and Hegemonic Power Relationships." International Planning Studies 16 (1): 61-72. 